\title{
PENERAPAN PICTURE AND PICTURE TERHADAP PEMAHAMAN MATERI PERSAMAAN KEDUDUKAN WARGA NEGARA INDONESIA DAN BUDAYA PADA MATA PELAJARAN PKn SISWA KELAS $X$ AP 3 SMK SWAKARYA BINJAI
}

\author{
Ema Sri Feronika $^{1}$, Ismail Manurung ${ }^{2}$ \\ Pendidikan Pancasila dan Kewarganegaraan, STKIP BUDIDAYA BINJAI
}

\begin{abstract}
ABSTRAK
Adapun tujuan penelitian ini adalah untuk meningkatkan hasil belajar siswa pada mata pelajaran PKn dengan menerapkan Metode Pembelajaran Picture and Picture di kelas X AP 3 SMK SWAKARYA BINJAI. Subjek penelitian ini adalah seluruh siswa kelas X AP 3 SMK SWAKARYA BINJAI yang berjumlah 34 orang. Adapun metode penelitian ini adalah penelitian tindakan kelas. Instrumen penelitian ini terdiri d ari lembar observasi, dan lembaran tes. Data tes dianalisis dengan menggunakan nilai ratarata dan persentase ketuntasan belajar, sedangkan data observasi dianalisis dengan rata-rata skor, skor tertinggi, skor terendah, selisih skor dan kisaran untuk tiap kriteria. Adapun temuan penelitian ini adalah aktivitas guru pada siklus I diperoleh rata-rata skor 30,5 dengan kriteria baik dan pada siklus II rata-rata skor aktivitas guru meningkat menjadi 33 dengan kriteria baik. Untuk aktivitas siswa pada siklus I diperoleh rata-rata skor 23 dengan kriteria cukup dan pada siklus II ratar-ata skor aktivitas siswa meningkat menjadi 30,5 kemudian untuk hasil data tes siklus I mendapat nilai rata-rata 6,46 dengan ketntuasan klasikal 50\% dan untuk siklus II diperoleh nilai rata-rata 8,06 dengan ketuntasan belajar klasik 184,61\%. Berdasarkan hasil penelitian tersbeut dapat disimpulan bahwa melalui metode pembelajaran Picture and Picture dapat meningkatkan hasil belajar siswa serta dapat meningkatkan aktivitas guru dan siswa dalam proses pembelajaran PKn khususnya di kelas X AP 3 SMK SWAKARYA BINJAI. Berdasrkan hasil penerapan dengan model pembelajaran picture and picture dapat dijadikan bahan acuan untuk mengadakan peneltian selanjutnya dari sudut permasalahan yang berbeda. Selain itu dapat diimplementasikan sebagai bahan kajian pendekatan pembelajaran bagi guru untuk diterapkan di kelas X AP 3 SMK SWAKARYA BINJAI sebagai alternative model pembelajaran.
\end{abstract}

Kata kunci: picture and picture, persamaan hak, budaya Indonesia.

\section{PENDAHULUAN}

\section{A. Latar Belakang Masalah}

Peningkatan mutu atau kualitas pendidikan pada semua jenjang pendidikan disekolah adalah bagian aktivitas siswa yang merupakan syarat mutlak bagi berlangsung interaksi balajar mengajar, baik aktif fisik maupun aktif mental kualiatas proses belajar mengajar yang dilakukan guru dan siswa di sekolah. Salah satu upaya peningkatan kualitas pendidikan di Indonesia. Peningkatan kualitas pendidikan di sekolah berkaitan erat dengan kesuksesan dari kegiatan belajar mengajar sangat dipengaruhi oleh dua faktor internail dan faktor eksternal dari siswa. Faktor internal adalah faktor yang berasal dari dalam diri siswa, antara lain motivasi belajar.
Menurut jurnal Rahmat Fauzi tentang penerapan metode pembelajaran picture and picture "Motivasi merupakan faktor pendorong yang ada pada diri seseorang untuk melakukan aktivitas tertentu demi tercapainya tujuan. Motivasi dalam kegiatan belajar dapat dikatakan sebagai keseluruhan daya penggerak didalm diri siswa menimbulkan, menjamin dan memberikan arah kegiatan belajar. Sedangkan faktor eksternal yaitu faktor yang berasal dari luar diri siswa atau berasal dari rangsangan pihak luar. Faktor tersebut antara lain metode pembelajaran dan interaksi sosial siswa".

Kemajuan ilmu pengetahuan dan teknologi di dunia pendidikan yang di ikuti oleh kemajuan di berbagai bidang lain merupakan konsekuensi logis dari pesatnya perkembangan teknologi pendidikan yang melanda dunia. Terbukanya arus informasi 
yang bersifat dua arah antar negara memungkinkan manusia saling berinteraksi satu dengan yang lain. Teknologi yang semakin maju juga membuka peluang bagi manusia untuk berkomunikasi dengan siapapun, kapanpun, dan dimanapun tanpa mengenal batas dan waktu serta memungkinkan manusia untuk tidak hanya mengakes informasi saja, namun juga memungkinkan manusia tersebut untuk menjelajah dunia.

Dalam rangka memahami identitas budaya setempat, seseorang harus menyiapkan mentalnya untuk bisa berinteraksi dengan masyarakat setempat. Identitas budaya seperti nilai-nilai sosial yang berbeda, adat istiadat, kebiasaan gaya hidup yang berbeda akan membawa sesorang berhadapan dengan dunia yang bener-bener berbeda, lingkungan yang bebeda, komunitas yang berbeda, kegiatan yang berbeda dan lain-lain. Identitas budaya yang berbeda juga mempunyai norma dan etika sopan santun yang berbeda pula antara negara satu dengan yang lainnya. Menurut pendapat Joko Suryo. Jurnal Widyatama No.1. Vol 19/2010. Mengatakan "Pemahaman mengenai norma dan etika sopan santun yang ada dinegara tujuan menajadi hal yang penting untuk mengantisipasi terjadinya guncang budaya (curtural shocks) yang tidak dapat terelakan dan mencari solusi yang tepat akan masalah itu".

Sebuah model pembelajaran dalam dunia pendidikan mengenai pemahaman mengenai persamaan kedudukan warga Negara Indonesia dan budaya dimanapun ia berada sehingga dipihak lain. Interaksi antara pengajaran dengan warga belajar, merupakan proses motivasi. Maksudnya, bagaimana dalam proses interaksi itu pihak pengajaran mampu memberikan dan mengembangkan motivasi serta penguatan (reinforcement) kepada pihak warga belajar/ siswa, agar dapat melakukan kegiatan belajar secara optimal.

"Sehubungan dengan hal tersebut perlu ditegaskan bahwa prinsip mengajar adalah mempermudah dan memberikan motivasi kegiatan belajar. Sehingga guru sebagai mengajar memiliki tugas memberikan fasilitas atau kemudahan bagi suatu kegiatan belajar subjek belajar/siswa. Dengan itu maka banyak masalah yang perlu diperhatikan oleh guru, antara lain":

1. Bagiamana guru harus dapat membimbing atau mengarahakan belajar siswa agar dapat mencapai tujuan pendidikan yang diharapkan?
2. Bagiaman bentuk bimbingan/ pengarahan tersebut, terutama untuk menangani jumlah siswa yang besar?

3. Dapatkah guru menyediakan waktu yang cukup?

4. Apakah setiap lembaga pendidikan mampu menyediakan tenaga guru yang lebih memadai?

5. Apakah proses belajar mengajar itu sudah didukung oleh fasilitas yang sempurna dan layak?

Sedangkan mengajar adalah kegiatan penyedian kondisi yang merangsang serta mengarahkan kegiatan belajar siswa/subjek belajar untuk memperoleh pengetahuan, ketersampilan, nilai dan sikap yang dapat membawa perubahan tingakh laku maupun perubahan serta kesadaran diri sebagai pribadi. Sehubungan dengan itu seseorang pengajar harus dapat memberikan pengertian kepada siswa bahwa belajar memiliki beberapa maksud antara lain:

1. Mengetahui sewaktu kepandaian kecakapan atau konsep yang sebelumnya tidak pernah diketahui.

2. Dapat mengerjakan sesuatu yang sebelumnya tidak dapat berbuat baik tingakah laku maupun ketererampilan

3. Mampu mengobinasikan dua yang sebelumnya tidak dapat kedalam suatu penegrtian baru, baik keterrampilan, pengetahuan, konsep maupun sikap/ tingkah laku.

4. Dapat memahami dan menerapkan pengetahuan yang telah diperoleh.

Dengan melihat beberapa maksud belajar seperti disebut diatas, faktor keaktifan siswa sebagai subjek belajar sangat menentukan. Memang pada kegiatan dimasa-masa lalu banyak interakasi belajar mengajar yang berjalan secara searah. Dalam hal ini fiungsi dan peranan guru menjadi amat dominan. Di lain pihak siswa hanya menyimak dan mendengar informais atau pengetahuan yang diberikan gurunya ini menjadikan kondisi yang tidak professional dan guru sangat aktif tetapi sebaliknya siswa menjadi pasif dan tidak kreatif. Bahkan kadang-kadang masih ada anggapan yang keliru yang memandang siswa sebagai objek. Sehingga siswa kurang dapat mengembangkan potensinya.

Mungkin pada mulanya, karena ada suseuatu bantuk motivasi siswa itu rajin belajara tetapi guru harus mampu melanjutkan dari tahap rajin belajar itu bisa diarahkan menjadi kegaiatan belajar yang bermakna, sehingga hasilnya pun akan bermakna bagi kehidupan si subjek belajar. Berdasarkan 
masalah diatas maka penelitain akan melakukan penelitin permasalahan ini dengan mengambil judul penelitian "Penerapan Picture and Picture Terhadap Pemahaman Materi Persamaan Kedudukan Warga Negara Indonesia dan Budaya Pada Mata Pelajaran PKn Kelas X AP 3 SMK SWAKRYA BINJAI.

\section{METODOLOGI PENELITIAN}

\section{A. Lokasi dan Waktu Penelitian}

Penelitian ini dilakukan di kelas X AP 3 SMK SWAKARYA BINJAI alasan penelitian memilih lokasi penelitian di sekolah $X$ AP 3 SMK SWAKARYA BINJAI karena judul Penerapan Picture and Picture Terhadap Pemahaman Materi Persamaan kedudukan Warga Negara Indonesia dan Budaya pada mata pelajaran PKn siswa kelas X AP3 SMK SWAKARYA BINJAI belum pernah di teliti.

\section{B. Subjek Penelitian}

Sebagai subjek penelitian ini adalah dilakukan pada siswa kelas X AP 3 SMK SWAKARYA BINJAI Tahun Pelajaran 2016-2017, berjumlah 40 mengingat bahwa:

a. Minat belajar dan motivasi belajar siswa di kelas terbilang rendah sehingga perlu di beri inovasi pembelajaran dengan menerapkan metode tanya jawab dengan variasi media pemebelajaran

b. Rendahnya hasil belajar siswa, yang berdasarkan informasi dari guru bidang studi PKn di sekolah tersebut nilai rata-rata PKn adalah 65, sehingga masih berada di bawah KKM yang ditetapakan oleh guru bidang studi PKn sebesar 75 .

\section{Sumber Data}

Sumber data dalam penelitian di dapat dari:

a. Sumber data primer di dapat dari nilai ulangan siswa

b. Sumber data sekunder di dapat dari hasil wawancara penelitian kepada pihak yang berkepentingan serta hasil observasi yang dilakukan oleh observer yang penelitian tunjuk sendiri dari pihak sekolah yaitu guru bidang studi PKn dari sekolah tersebut.

\section{Teknik Pengumpulan Data}

Teknik pengumpulan data dalam penelitian ini di peroleh melalui observasi dan catatan data lapangan, wawancara, hasil tes dan catatan hasil refleksi/diskusi yang dilakukan oleh penelitian dan mitra penelitian. Penentuan teknik tersebut didasarkan ketersedian sarana dan prasana dan kemampuan yang dimiliki peneliti.

Uraian lebih lanjut mengenai teknik-teknik pengumpulan data tersebut adalah berikut:

\section{a. Observasi dan catatan data lapangan}

Observasi dalam kegiatan PTK merupakan kegiatan pengamatan terhadap aktivitas yang dilakukan penelitian selama melaksanakan kegiatan belajar mengajar di kelas. Kegiatan ini dilakukan oleh pengamatan (observer ) yang dalam hal ini adalah mitra penelitian. Bentuk kegiatan observasi yang dilakukan dalam PTK ini menggunakan model observasi terbuka. Adapun yang dimaksud observasi terbuka adalah apabila pengamatan atau observer melakukan pengamatan dengan mencatatkan segala sesuatu yang terjadi di kelas. Hasil pengamatan dari mitra penelitian selanjutnya di jadikan catatan data lapangan. Hal ini sesuai dengan pendapat Rochiati Wiriaatmaja yang menyatakan "sumber informasi yang sangat penting dalam penelitian ini PTK adalah catatan lapangan yang dibuat oleh penelitian/mitra penelitian yang dilakukan pengamatan atau obeservasi".

\section{b. Hasil Tes}

Hasil tes yang dimaksud adalah hasil berupa nilai yang diperoleh melalui ujian presentest maupun post tes. Hasil ini dapat di jadikan bahan perbandingan anatara hasil dari masing-masing yang didapat dari setiap siklus.

\section{c. Catatan Hasil Refleksi}

Adapun yang dimaksud catatan hasil refleksi adalah catatan yang di perolah dari hasil

refleksi yang di lakukan dengan melalui kegiatan diskusi antara penelitian dan mitra penelitian dimana bahanya ddidapat dari hasil observasi dan wawancara. Hasil refleksi ini selain dijadikan bahan dalam penyusunan rencana tindakan selanjutnya juga digunakan sebagai sarana untuk mengetahui telah tercapai tidaknya tujuan kegiatan penelitian ini.

\section{E. Intrumen Penelitian}

Menurut Sugiyono mengatakan " Instrumen yang digunakan untuk mengukur variabel dalam ilmu alam sudah banyak tersedia dan telah teruji vadilitas dan relibilitasnya".

Menurut Arikunto " Tes adalah sederetan pertanyaan atau latihan yang dengan menggunakan 
latihan pengetahuan intelegensi kemampuan atau bakat yang dimiliki individu atau kelompok".

Tes yang digunakan adalah tes formatis atau tes esai.

Formatif tes/ test esai

Tes formatif adalah tes hasil belajar untuk mengetahui keberhasilan proses belajar mengajar yang dilakukan oleh guru, guna memperoleh umpan balik dari upaya pengajaran yang dilakukan oleh guru.

1. Soal tes

Soal tes digunakan untuk mengukur prestasi belajar siswa. Tes yang dibuat merupakan pertanyaan-pertanyaan singkat dan siswa menjawab dengan jawaban yang bener. Soal yang dibuat disusun berdasarkan indicator pada tiap siklus.

\section{F. Teknik Analisis Data}

Analisis data dalam PTK ini dilakukan sejak awal, artinya analisis data dilakukan tahap demi tahap atau siklus demi siklus. Hal ini sesuai dengan pendapat Miles dan Huberman dalam Rochianti Wiriaatmaja bahwa "ini berarti model ideal dari pengumpulan data analisis adalah yang secara bergantian berlangsung sejak awal".

Kegiatan analisis data akan dilakukan mengacu pada pendapatan Rochianti Wiriaantmaja "dengan malakukan catatan refleksi yakni pemikiran yang timbul pada saat menganti dan meruapakn hasil proses membandingkan, mengaitkan atau menghubungkan data yang ditampilkan dengan data sebelumnya. Gambar hasil pelaksanaan refleksi tersebut dibuat dalam bentuk matrik agar terlihat lebih jelas dan mudah dipahami secara substansif'.

\section{HASIL PENELITIAN DAN PEMBAHASAN}

\section{A. Deskripsikan Hasil Penelitian \\ 1. Kegiatan pra Tindakan}

Sebelum proses penelitian dilaksanakan terlebih dahulu penelitian mengadakan pra survei pada tanggal 19 oktober 2016. Kegiatan ini dilakukan dengan tujuan menyampaikan maksud mengadakan penelitian tindakan kelas dengan menerapkan model picture and picture untuk meningkatkan hasil belajar siswa dalam proses pembelajaran. Perencanaan kegiatan sebelum penelitian:

1. Urutan Tindakan

a. Survei dan penjajakan

Survei dan penajajakan dilakukan secara langsung untuk mengetahui kemungkinan dan ketersediaan sekolah yang bersangkutan untuk dijadikan tempat penelitian. Tujuan survei yang lain adalah mendapatkan informasi baik fisik maupun non fisik keadaan sekolah dan sarana pembelajaran.

b. Perijinan

Perijinan diperoleh dengan prosedur yang ada dengan ijin dan rekomedasi lembaga terkait untuk perjanjian kelapangan.

2. Pelaksanaan Penelitian

Untuk melaksanakan penelitian, diperlukan suatu rancangan yang dijadikan pedoman dalm proses pembelajaran. Rencana penelitian ini merupakan suatu rancangan model picture and picture sehingga dapat mencapai tujuan yang diharapkan.

Secara umum model picture and picture adalah untuk memperoleh hasil pembelajaran, untuk memecahkan suatu masalah atau mendiskusikan. Suatu pembelajaran dengan mengguanakan model picture and picture, diharapkan dapat menggali hasil pembelajaran melalui picture and picture. Dengan picture and picture siswa dapat melatih diri untuk lebih memahami materi tersebut, sehingga pembelajaran yang diharapkan dengan picture and picture pembelajaran aktif kretatif dan menyenangkan dan dapat dipahami. Tugas guru selama proses pembelajaran berlangsung adalah menyampaikan tujuan pembelajaran sejalas-jelasnya, memantau hasil belajar siswa dan memberi bantuan kepada siswa untuk memaksimal proses pembelajaran. Sementara itu siswa dituntut untuk lebih aktif dalam menganalisa permasalahan dengan penuh tanggung jawab.

Dalam bab ini akan dipaparkan hasil penelitian yang meliputi pelaksanaan post tes siklus I, pelaksanaan post tes siklus II dan pengamatan terhadap penelitian yang dilakukan teman sejawad serta keterlibatan siswa pada proses pembelajaran.

a. Hasil Pelaksanaan Tes Awal.

Sebelum melakukan perencanaan tindakan dilakukan, terlebih dahulu penelitian memeberikan tes awal yang bertujuan selain untuk mengetahui kemampuan awal siswa juga untuk mengetahui gambaran-gambaran kesulitan yang dialami siswa dalam menyelesaikan soal-soal dengan ketuntasan minimal sebesar 75 untuk siswa yang memperoleh nilai dibawah 75 maka dapat dikatakan bahwa siswa tersebut belum tuntas dan setelah diberi soal pre tes maka hasil belajar siswa dapat dilihat dilampiran. 
Untuk mencari nilai siswa secara individu seperti yang ada pada tabel digunakan Rumus Nilai $=\underline{\text { Skor yang diperolah }} \times 100$

Skor maksimum

Nilai $\underline{12} \times 100=30 \%$

\section{0}

Dan untuk meperolah ketuntutasan siswa kalsikal menggunakan rumus:

$\mathrm{P}=\left\{\begin{array}{l}\frac{\text { siswa yang tuntas }}{\text { Siswa }} \times 100 \\ \mathrm{P}=12 \times 100=30 \%\end{array}\right.$

$\mathrm{P}=\underline{12} \times 100=30 \%$

40

Dari data diatas ketuntasan belajar siswa secara klasikal sebesar (30, 5\%). Secara ringkas tingkat keberhasilan siswa saat diberikan pre tes dapat dilihat pada tabel.

Tabel 1.. Tabel Hasil belajar Awal

\begin{tabular}{ccc}
$\begin{array}{c}\text { Tingkat } \\
\text { Hasil } \\
\text { belajar }\end{array}$ & $\begin{array}{c}\text { Jumlah } \\
\text { siswa }\end{array}$ & Keterangan \\
\hline $28-32$ & & Sangat baik ( SB ) \\
\hline $23-27$ & 12 & Baik (B) \\
\hline $18-22$ & 10 & Cukup (C) \\
\hline $13-17$ & 8 & Kurang (K) \\
\hline $8-12$ & 10 & Sangat kurang (SK)
\end{tabular}

Tabel 2. Hasil Tes awal ( Pre tes )

\begin{tabular}{cc} 
Prensentase Rata-rata & Kategori \\
\hline $80 \%$ atau lebih & Sangat Baik \\
\hline $60 \%-79,99 \%$ & Baik \\
\hline $40 \%-59,99 \%$ & Cukup \\
\hline $20 \%-39,99 \%$ & Kurang \\
\hline $0 \%-19,99 \%$ & Sangat Kurang
\end{tabular}

Berdasarkan tabel di atas diketahui bahwa hasil tes awal (pretes ) kerajinan mengayam belum tuntas ( dari 40 siswa dari 28 orang masih belum tuntas). Serta dapat dikatagorikan masih rendah. Selanjutnya yang mendekati tuntas berkisar $41 \%$ atau 12 orang, lebih rinci dapat dilihat diabawah ini: 12 orang siswa ( $3 \%$ ) yang memiliki ketuntasan belajar kategori sangat tuntas 10 orang siswa ( $38 \%$ ) yang memiliki belajar kategori tuntas 8 orang siswa ( $34 \%$ ) yang memiliki ketuntasan belajar kategori kurang tuntas dan 10 orang siswa $(25 \%)$ yang memilki ketuntasan belajar kategori tidak tuntas. Jadi total perolehan nilai rata-rata 53.37

Tabel 3. Nilai Hasil Belajar Pre Tes

\begin{tabular}{ccccc} 
Nilai & F & $\%$ & $\begin{array}{r}\text { Belum } \\
\text { Tuntas }\end{array}$ & Tuntas \\
\hline 20 & 4 & 12.5 & $\checkmark$ & \\
\hline
\end{tabular}

\begin{tabular}{|c|c|c|c|}
\hline 30 & 9.37 & $\checkmark$ & \\
\hline 40 & 6.25 & $\checkmark$ & \\
\hline 50 & 18.75 & $\checkmark$ & \\
\hline 60 & 25 & $\checkmark$ & \\
\hline 70 & 18.75 & & $\checkmark$ \\
\hline 80 & 9.37 & & $\checkmark$ \\
\hline Jumlah nilai & 1720 & & \\
\hline $\mathrm{N}$ & 40 & 29 & 11 \\
\hline Rata-Rata Nila & 53.75 & & \\
\hline $\begin{array}{l}\text { Presentase } \\
\text { Ketuntasan }\end{array}$ & & 69,4 & $30,2 \%$ \\
\hline
\end{tabular}

Dari hasil pre tes pada tabel diatas, hasil belajar siswa rendah dimana 29 siswa ( 71, $8 \%$ ) tingkat penguasaan belum tuntas dan 11 orang siswa (30. $2 \%$ ) tingkat penguasan tuntas walaupun nilai yang dimiliki tidak begitu tinggi. Sedangkan nilai ratarata yang diperolehj siswa pada pre tes ini sebesar 53,75 maka perlu adanya perencanaan untuk meningkatkan hasil belajar siswa menggunakan model picture and picture agar meningkatkan hasil belajar siswa.

Berdasarkan data yang telah diperoleh dari hasil pre tes penelitian harus melaksanakan perbaikan pengajaran pada siklus I agar nantinya siswa dapat menyelesaikan post tes siklus I dengan memperoleh ketuntasan belajar baik secara individu maupun klasikal.

\section{Pelaksanaan Tindakan}

Sebelum penelitian melakukan pelaksanaan terlebih dahulu membuat langkah-langkah- langkah pembelajaran yaitu melaksanaakan doa, memeriksa absensi siswa melihat kebersihan kelas, memberi tahu aturan main, pormasi dan lain-lain. Setelah semua dilakukan, penelitian melihat kesepian siswa dan menginformasi tujuan yang akan di capai yaitu menjelaskan pengertian perwujudan asas persamaan melalui prinsip kesetaraan.

Dalam kegiatan yang tersebut penelitian melibatkan siswa mencari informasi yang luas dan dalam topik materi yang akan dipelajari tanpa membatasi siswa menggunakan pendekatan pembelajaran media pembelajaran serta sumber belajar lainnya. Penelitian dalam menjelaskan aturan main juga memfasilitasi agar terjadi interaksi antara siswa, dan guru, lingkungan dan sumber belajar lainya tidak lupa penelitian juga mengajukan pertanyaan kepada siswa untuk menyatakan pendapat yang ditindak lanjuti penelitian dengan mencatat semua pendapatpendapat siswa kemudian penelitian membacakan 
satu persatu pendapat-pendapat tersebut dan menjelaskan satu persatu sampai selesai.

Penelitian juga memberikan kesempatan kepada siswa untuk bertanya atas penjelasan penelitian atas pendapat-pendapat mereka dan setelah siswa selsai memberikan pertanyaan atau hal-hal yang ingin mereka perjelasan penelitian dapat memberikan post test siklus I yang tetap dibimbing oleh penelitian hingga penelitian mengumpulkan hasil tugas.

Tidak lupa pula penelitian memotivasi siswa agar tetap selalu berani mengeluarkan pendapat untuk memperoleh wawasan yang lebih baik. Hasil post tes siklus I dapat dilihat dilampiran.

Tabel 4.Distribusi Nilai Hasil Belajar (Pos Tes I)

\section{Belum}

\begin{tabular}{ccclc} 
Nilai & F & $\%$ & Tuntas & Tuntas \\
\hline 30 & 2 & 6,25 & $\checkmark$ & \\
\hline 40 & 3 & 6,25 & $\checkmark$ & \\
\hline 50 & 4 & 6,25 & $\checkmark$ & \\
\hline 60 & 6 & 15,65 & $\checkmark$ & \\
\hline 75 & 16 & 40,63 & & $\checkmark$ \\
\hline 80 & 9 & 25 & & $\checkmark$ \\
\hline Jumlah Nilai & 2155 & & \\
\hline \multicolumn{5}{c}{$\mathrm{N}$} \\
\hline $\begin{array}{c}\text { Rata-Rata } \\
\text { Nilai }\end{array}$ & 67,34 & & \\
\hline $\begin{array}{l}\text { Persentase } \\
\text { Ketuntasan }\end{array}$ & & 34,375 & 65,50
\end{tabular}

Dari data di atas terlihat bahwa kemampuan siswa dalam memahami pelajaran PKn dengan materi perwujudan asas persamaan melalui prinsip kesetaraan masih tergolong rendah terdapat 14 orang siswa atau sebesar $34,375 \%$ yang belum tuntas dalam belajar dan sebanyak 26 orang atau sebesar $67,50 \%$ yang telah mencapai standar ketuntasan belajar dengan rata-rata nilai secara klasikal sebesar 67,25

\section{Observasi}

Selama kegiatan berlangsung diadakan observasi secara langsung terhadap hasil belajar siswa dalm pembelajaran PKn. Pada pertemuan pertama ini jumlah siswa yang masuk sebanyak 20 siswa $(100 \%)$ dari 20 siswa. Hasil belajar siswa pada pertemuan pertama ini masih rendah atau belum sesuai dengan yang diharapkan. Siswa masih pasif dalam mengikuti pembelajaran. Masalah yang dihadapi yaitu siswa sibuk sendiri dan mengobrol dengan teman-temannya pada saat diskusi berlangsung, siswa ada yang melamun siswa dan bertanya dan menjawab asal-asalan. Pada pertemuan pertama ini tidak semua kelompok mempersentasikan hasil diskusinya didepan kelas karena keterbatasan waktu.

Hasil observasi pada pertemua pertama ini dapat dilihat pada tabel berikut ini

Tabel 5. Hasil Belajar Siswa Pada Pertemuan I siklus I

\begin{tabular}{llcc}
\multicolumn{1}{c}{ Aspek yang diamati } & F & F\% \\
\hline 1. & Mengajukan pertanyaan & 4 & 13,33 \\
\hline $\begin{array}{l}\text { 2. } \\
\text { lain }\end{array}$ & 6 & 20 \\
\hline 3. & $\begin{array}{l}\text { Menjangawabi respon siswa } \\
\text { guru. }\end{array}$ & 6 & 20 \\
\hline 4. & $\begin{array}{l}\text { Memperhatikan penjelasan } \\
\text { guru }\end{array}$ & 21 & 70 \\
\hline 5. & Diskusi kelompok & 14 & 46,67 \\
\hline 6. & Diskusi kelas & 19 & 63,33 \\
\hline
\end{tabular}

Pada tabel di atas dapat ditunjukan bahwa siswa yang mengajukan pertanyaan sebesar 4 siswa $(13,33 \%)$, menanggapi respon siswa lain sebesar 6 siswa (20\%), menjawab pertanyaan guru sebesar 6 siswa ( 20\%), memperhatikan penjelasan guru sebesar 21 siswa (70\%), diskusi kelompok sebesar 14 siswa $(46,67 \%)$ diskusi kelas sebesar 19 siswa $(63,33 \%)$

Pada pertemuan pertama ini guru belum melakukan apersepsi. Guru sudah menjelaskan materi pembelajaran sesuai dengan rancangan yang telah ditetapkan. Selain itu guru menjawab pertanyaan yang diajukan oleh siswa, guru terlihat belum dapat mengelola diskusi dengan baik, sehingga masih banyak siswa yang asyik ngobrol dengan temannya. Guru selalu menganjurkan agar siswa bekerjasama dalam diskusi, tetapi pada kenyataannya siswa cenderung bekerja sendirisendiri. Pada pertemuan pertama ini guru belum merangkum dan menyimpulkan masalah karena waktu yang diberikan untuk diskusi melebihi dari waktu yang telah direncanakan.

Tabel 6 Hasil Belajar Guru Pada Pertemuan 1, siklus 1

Aspek yang diamati $\quad$ Ya Tidak

\begin{tabular}{llcc}
\hline 1. & Melakukan apersepsi & & $\checkmark$ \\
\hline 2. & Menjelaskan materi & $\checkmark$ & \\
\hline 3. & Mengajukan pertanyaan & & $\checkmark$ \\
\hline 4. & $\begin{array}{l}\text { Menjawab pertanyaan } \\
\text { siswa }\end{array}$ & $\checkmark$ & \\
\hline 5. & $\begin{array}{l}\text { Memberi komentar } \\
\text { siswa }\end{array}$ & & $\checkmark$ \\
\hline 6. & Memunculkan masalah & $\checkmark$ & \\
\hline 7. & Menyimpulkan diskusi & & $\checkmark$
\end{tabular}


8. Membentuk kelompok

\begin{tabular}{lll}
\hline 9. $\begin{array}{l}\text { Menentukan waktu } \\
\text { lamanya diskusi }\end{array}$ & $\checkmark$ \\
\hline 10. Mengarahkan & $\checkmark$ & \\
\hline 11. Memantau kerja siswa & & $\checkmark$
\end{tabular}

\section{Refleksi}

Pembelajaran pada siklus I ini dilakukan agar siswa dapat memahami materi perwujudan asas persamaan melalui prinsip kesetaraan dengan penerapan model picture and picture. Pada siklus 1 ini belum dilaksanakan secara optimal, karena siswa belum terbiasa dengan metode ini sehingga hasil belajar yang diharapkan belum maksimal. Hasil belajar siswa dalam mengikuti pembelajaran masih bingung dengan metode pembelajaran yang dilakasanakan oleh guru. Selain itu diperoleh nilai rata-rata 6.39 kerena siswa belum terbiasa mengguanakan model picture and picture yang masih baru dan asing bagi mereka.

Berdasarkan uraian di atas maka tujuan yang ingin dicapai dari pembelajaran pada siklus 1 berikutnya. Dilihat dari hasil belajar siswa pada siklus 1 ini ada beberapa dari hasil belajar siswa sudah muncul dianataranya hasil belajar mengajukan pertanyaan, diskusi kelompok dan diskusi kelas. Sedangkan hasil belajar guru dalam mengelola kelas agar siswa aktif dalam kegiatan pembelajaran membimbing diskusi kelompok dan mengajarkan siswa untuk saling bekerjasama dalam kelompok masih perlu diingat lagi. Berdasarkan hasil dari diskusi silkus 1 ini maka selanjutnya pada siklus II rancangan pembelajaraan harus dapat dilaksankan dengan lebih menarik dan menyenangkan bagi siswa sehingga pembelajaran dapat berjalan dengan lancar.

\section{Pertemuan 2}

\section{Pelaksanaan Tindakan}

a. Guru membuka pelajaran dengan mengucap salam, melakukan presensi secara singkat dan memnyampaikan kopetensi dasar yang akan dicapai.

b. Sebelum guru menyampaikan materi pembelajaran, terlebih dahulu guru menjelaskan metode pembelajaran yang akan diterapkan, kemudian menyampaikan tata cara siswa melakukan kegiatan dalam pembelajaran tersebut.

c. Siswa membentuk kelompok dengan anggota yang sebagian besar sama dengan anggota kelompok pada pertemuan sebelumnya. Kemudian guru memberikan kepada setiap kelompok untuk mencari solusi dari permasalahan yang telah dipaparkan oleh guru, siswa dengan anggota kelompok bekerja sesuai dengan aturan pembelajaran model picture and picture

d. Siswa dengan bimbingan guru, melaksankan rencana belajar yang telah disepakati dengan menfaatkan sumber belajar dan mengumpulakn informasi dan fakta yang relevan.

e. Prestasi hasil diskusi kelompok dilakukan oleh beberapa kelompok yang dirasa siap untuk mempersentasikan hasil diskusinya. Kelompok lain memberikan tanggapan terhadap hasil diskusi yang sedang dibahas.

f. Selanjutnya pada kegiatan penutup, guru menyimpulkan hasil presentasi dan memberikan kesempatan kepada siswa untuk menanyakan hal-hal yang belum dimengerti tentang materi yang telah dipelajari. Beberapa siswa menanyakan hal-hal yang belum dimengerti, kemudian guru menjelaskan secara klasikal. Setelah Tanya jawab guru dengan siswa berakhir, guru kemudian menutup pelajaran di pertemuan berikutnya. Kemudian guru menutup pelajaran dengan mengucap salam.

\section{Observasi}

Selama kegiatan berlangsung diadakan observasi secara langsung terhadap hasil belajar siswa dalam pembelajaran PKn. Pada pertemuan pertaman ini jumlah siswa yang masuk sebanyak 27 $(90 \%)$. Hasil belajar siswa pada pertemuan kedua ini masih relatif rendah atau belum sesuai yang diharapkan walaupun sudah ada peningkatan beberapa nomor item. Pertemuan kedua ini siswa mulai terlihat agak memeperhatikan dalam mengikuti pelajaran. Pada saat diskusi kelompok masih ada beberapa siswa yang ngobrol dengan temannya, sementara siswa yang lain sedangkan mengerjakan tugas, dalam diskusi kelompok sudah Nampak kerjasama yang baik, saling mengahargai dan mendukung antara anggota kelompok. Hasil observasi pada pertemuan kedua ini dapat dilihat dilampir.

Untuk menghitung persentase keterlibatan siswa digunakan rumus:

$\mathrm{P}=\underline{\text { Skor keseluruhan yang diperoleh dari observasi }}$ $\mathrm{x} 100 \%$ 
Skor maksimal x banyaknya butir observasi

$\mathrm{P}=\underline{23} \times 100 \%=57,5 \%$

$10 \times 4$

Dari data maka rata-rata yang diperoleh siswa adalah 57,5 \% dan digolongkan cukup. Dengan demikian dapat dikatakan bahwa keterlibatan siswa selama proses pembelajaran berlangsung masih rendah. Sementara dari observasi terhadap peneliti (guru) diperoleh keterangan bahwa proses pembelajaran yang dilaksanakan guru berjalan dengan lancar. Dalam hal melaksanakan serta langkah pembelajaran yang dilakukan oleh guru ketika membimbing siswa dalam mengemukakan pendapat, siswa dapat memahami dan memberi respon ketika siswa dapat memberi respon maka dengan memberikan pengahargaan dan ketika dapat menjelaskan makna dari pendapat-pendapat yang telah dikekumakakan siswa dalam pembelajaran. Berikut ditampilkan hasil observasi terhadap penelitian (guru) yang berperan terhadap siklus 1 dapat dilihat dilampiran.

Untuk menghitung persentase kamampuan guru digunakan rumus:

$\mathrm{P}=\underline{\text { Skor keseluruhan yang diperoleh dari observasi }}$ Skor maksimal $x$ banyaknya butir observasi

$\mathrm{P}=\underline{51} \times 100 \%=70,8 \%$

$18 \times 4$

\section{Refleksi}

Pembelajaran pada siklus I dilakukan agar siswa dapat memahami materi perwujudan asas persamaan melalui prinsip kesetaraan dengan penerapan model picture and picture. Pada siklus I ini belum dilaksanakan secara optimal, karena siswa belum terbiasa dengan metode ini. Sehingga hasil belajar yang diharapkan belum maksimal. Hasil siswa dalam mengikuti pembelajaran masih bingung dengan metode pembelajaran yang dilakukan oleh guru. Selain itu diperoleh nilai ratarata 6,93 karena siswa belum terbiasa menggunakan model picture and picture yang masih baru dan asing bagi mereka.

Berdasarkan uraian di atas maka tujuan yang ingin tercapai dari pembelajaran pada siklus I belum tercapai dan dari kegiatan pembelajaran perlu diajukan pada siklus berikutnya. Dilihat dari hasil belajar siswa pada siklus I ini ada beberapa hasil belajar siswa sudah muncul, dianataranya hasil belajar mengajukan pertanyaan, diskusi kelompok dan diskusi kelas. Sedangkan hasil belajar guru dalam mengelola kelas agar siswa untuk saling bekerjasama dalam kelompok masih perlu diingat lagi. Berdasarkan hasil dari siklus I ini masih selanjutnya pada siklus II rancangan pembelajaran harus dapat dilaksakan dengan lebih menarik dan menyengkan bagi siswa sehingga pembelajaran dapat berjalan dengan lancar.

\section{a. Siklus II}

\section{Perencanaan Tindakan}

a. Standar Kompetensi: Menghargai persamaan kedudukan warga negara dalam berbagai aspek kehidupan

b. Kompetensi Dasar: mendeskripsikan pengertian persamaan kedudukan warga Negara tanpa membedakan ras, agama, gender, golongan, budaya dan suku.

c. Materi: contoh kedudukan warga Negara tanpa membedakan ras, agama, gender, golongan, budaya dan suku.

d. Hipotesis Tindakan :

1. Upaya meningkatkan hasil belajar dengan materi mengahargai persamaan kedudukan warga negara dalam berbagai aspek kehidupan dengan penerapan model picture and picture

2. Peningkatan hasil belajar pada materi contoh kedudukan warga Negara tanpa membedakan ras, agama, gender, golongan, budaya dan suku dengan menerapkan picture and picture dapat dibuktikan dengan membandingkan antara nilai ratarata tes akhir siklus II.

\section{Pelaksanaan Tindakan}

Sebelum peneliti melakukan pelaksanaan tindakan pada siklus II terlebih dahulu membuat langkah-langkah pembelajaran yaitu melaksanakan doa, memeriksa absensi siswa, melihat keberhsihan kelas, member tahu aturan main, pormasi dan lainlain. Kegiatan pembelajaran dilakukan merupakan pengembangan pembelajaran yang dibuat sebelumnya dengan pengembangan dari kelemahan pada siklus I. Dengan tujuan pembelajaran yaitu menjelaskan pentingnya kehidupan berbudaya, menjelaskan akibat jika tidak menerapkan kehidupan berbudaya. Dalam pelaksanaan kegiatan sebagai upaya dalam meningkatkan kemampuan siswa pada materi menjelaskan pentingnya kehidupan berbudaya dalam bermasyarakat, berbangsa dan bernegara.

Setelah itu penelitian mengarahkan siswa menyusun meja dan kursi tidak lupa juga penelitian dan siswa membahas tentang hasil kerja siswa pada post tes siklus I, untuk mengetahui kesulitan dan 
kurungan yang dialami siswa agar lebih berkonsentrasi pada pembelajaran di siklus II. Selanjutnya setalah selesai penelitian menjelaskan materi pelajaran yang akan diberikan pada siswa kembali peneliti menjelaskan pemecahan masalah serta menstimulasi siswa agar bersedia dan siap mengikuti siklus II serta tidak ragu atau senantiasa berani selalu menyatakan pendapatnya tentang materi yang dijelaskan tersebut. Langkah yang dilakukan penelitian selanjutnya yaitu melemparkan pertanyaan kepada siswa untuk menyatakan pendapatnya tentang materi pembelajaran dan peneliti juga memotivasikan siswa lain untuk berani menanggapi pendapat temannya, mencatat pendapat-pendapat, membacakan seluruh pendapat siswa satu persatu kemudian penelitian juga menjelaskan makna pengertian atau konsep dari pendapat-pendapat siswa satu persatu.

Tidak lupa penelitian memberikan kesempatan kepada siswa untuk bertanya, serta berdiskusi dengan siswa sesuai dengan kesulitan-kesulitan yang dialami siswa, akhir atas langkah pelaksanaan siklus II ini penelitian melakukan tes yang dibimbing, Untuk mengetahui peningkatan hasil belajar siswa.

Dalam menutup pelaksanaan siklus II ini penelitian bersama-sama dengan siswa membuat rangkuman atau kesimpulan pembelajaran dan tetap memberikan semangat pada siswa kelas X AP 3 SMK SWAKARYA BINJAI. Serangan yang telah melaksanaan pembelajaran agar tetap berani mengeluarkan pendapat atau respon dalam pembelajaran PKn selanjutnya.

Setelah diberikan tabel tes siklus II maka diperoleh hasil belajar siswa yang tercantum dalam 'tabel tes hasil belajar siswa dengan menggunakan penerapan pemecahan masalah dengan materi pembelajaran hubungan internasional yang berlaku dimasyarakat pada siklus II dapat dilampiran.

Dengan tercapainya tingakt ketuntasan hasil siswa maka dapat dilihat secara ringkas pada tabel.

Tabel 7. Distribusi Nilai Hasil Belajar Post Tes Siklus II

\begin{tabular}{ccccc} 
Nilai & F & \% & $\begin{array}{c}\text { Belum } \\
\text { Tuntas }\end{array}$ & Tuntas \\
\hline 60 & 3 & 9,37 & & $\checkmark$ \\
\hline 75 & 5 & 12,5 & & $\checkmark$ \\
\hline 80 & 15 & 40,62 & & $\checkmark$ \\
\hline 90 & 6 & 15,62 & $\checkmark$ & \\
\hline 100 & 7 & 21,87 & $\checkmark$ & \\
\hline Jumlah Nilai & 2670 & & \\
\hline \multicolumn{6}{c}{ N } & 40 & 37 & 3 \\
\hline
\end{tabular}

\begin{tabular}{cccc}
\hline $\begin{array}{c}\text { Rata-rata } \\
\text { Nilai }\end{array}$ & 83,43 & & \\
\hline $\begin{array}{c}\text { Persentase } \\
\text { Ketuntasan }\end{array}$ & & $9,38 \%$ & $90,62 \%$
\end{tabular}

Dari tabel diatas dapat dilihat bahwa terjadi peningkatan secara deskritif. Nilai rata-rata kelas dari 67, 34 pada tes siklus I menjadi 83,43 pada siklus II.

Dari 13 siswa $(34,37 \%)$ yang belum mencapai ketuntusan belajar pada siklus I menjadi 3 siswa $(9,37 \%)$ pada siklus II dari 23 siswa $(65,625)$ mencapai ketuntasan belajar pada siklus I menjadi 33 siswa $(90,62 \%)$ pada siklus II.

Diliahat dari tingakat ketuntasan belajar secara klasikal telah tercapai. Kerena kelas tersebuit telah mencapai ketuntutasan belajar maka upaya yang telah dilakukan untuk meningkatkan hasil belajar siswa sudah tercapai dan tidak perlu melakukan siklus berikutnya.

\section{Observasi}

Disiklus ini guru selalu memberikan motivasi dan bimbingan pada proses pembelajaran siswa selalu merasa senang dan berani mengeluarkan pendapat dan menanggapi pendapat temannya. Berdasarkan hasil tes pada siklus II hasil pembelajaran sudah mencapai tingakat ketuntusan belajar. Dari hasil observasi terhadap siswa. Siswa telah mengalami peningkatan baik itu dari segi interaksi maupun hasil belajar siswa. Siswa sudah mampu menanggapi pendapat temannya dengan baik, berani mengajukan pertanyaan, mampu memberikan kritik saran atau solusi yang baik terhadap pemecahan masalah dan mampu mengerjakan tugas yang diberikan oleh guru. Ini dapat dilihat pada rata-rata keterlibatan siswa pada siklus II pokok pembahasan hubungan internasional yang berlaku dimasyarakat yang mencapai skor 36 ( 90\%) dan digolongan sangat baik.

Berdasarkan observasi diatas terlihat bahwa kegiatan pembelajaran yang dilakukan peneliti pada tahap awal, tahap inti dan tahap akhir dalam pelaksaan disiklus sudah meningkat skor yang diperoleh 94, 4\% digolongkan pada kategori sangat baik dapat dilihat pada lampiran.

Berikut disampaikan hasil observasi terhadap peneliti yang berperan sebagai guru pada siklus II dapat dilihat pada lampiran.

\section{Refleksi}

Berdasarkan hasil yang telah dilakukan maka diperoleh hasil pada siklus II yang rata-rata 
tes hasil belajar diproleh 83,43 dimana 29 orang siswa $(90,62)$ siswa sudah mencapai tingkat ketuntasan belajar, sedangkan 3 orang siswa $(9,37)$ belum mencapai tingkat ketuntusan belajar. Dilihat dari pengamatan selama proses pembelajaran yang diajarkan. Keaktifan dan aktinya seluruh siswa dalam kegaiatan yang berlaku sehingga peningkatan nilai tes dapat tercapai dengan baik.

Data-data ini akan dijadikan acuan untuk mencangkup kegiatan tersebut dengan tidak melanjutkan pada siklus berikunya. Kesimpulan yang dapat diambil bahwa pembelajaran dengan model picture and picture telah meningkatkan hasil belajar siswa dalam memahami pelajaran PKn pada materi menunjukan persamaan kedudukan warga Negara tanpa membedakan ras,agama dan budaya siswa kelas X AP 3 SMK SWAKARYA BINJAI Tahun Pelajaran 2016/2017

Pada akhir pertemuan setiap siklus dilakukan tes untuk mengetahui sejauh mana model picture and picture dapat mempengaruhi hasil belajar siswa. yang kemudian dicari nilai rata-rata tes per siklus. Adapun rata-rata te siklus I dan II :

Tabel 8. Perbandingan Nilai Rata-Rata Tes Siklus I, II

\begin{tabular}{cc} 
Siklus I & Siklus II \\
\hline 67,25 & 83,43
\end{tabular}

Dari tabel di atas dapat diketahui bahwa skor nilai rata-rata nilai $\mathrm{PKn}$ mengalami peningkatan yaitu pada siklus I sebesar 67,25 dan siklus II sebesar 83,453. Hasil belajar siswa dalam pembelajaran juga dipengaruhi hasil belajar guru dalam melaksanakan proses pembelajaran. Sehingga selain melakukan pengamatan terhadap siswa, penelitian juga melakukan pengamatan terhadap hasil belajar guru di kelas.

Tabel 9. Hasil Belajar Siswa Siklus II

\begin{tabular}{lcc} 
Aspek yang diamati & F & F\% \\
\hline 1.Mengajukan pertanyaan & 3 & $9,37 \%$ \\
\hline $\begin{array}{c}\text { 2.Menanggapi respon siswa } \\
\text { lain }\end{array}$ & 5 & $12, \%$ \\
\hline 3.Menjawab pertanyaan guru & 15 & 40,62 \\
\hline $\begin{array}{c}\text { 4.Memperhatikan penjelasan } \\
\text { guru }\end{array}$ & 6 & 15,62 \\
\hline 5.Diskusi kelompok & 7 & 21,87
\end{tabular}

Pada tabel di atas dapat ditunjukan bahwa siswa yang mengajukan pertanyaan sebesar 3 siswa $(9,37 \%)$ menanggapi respon siswa lain sebesar 5 siswa $(12,5 \%)$ menjawab pertanyaan guru 6 siswa
$(15,62 \%)$ diskusi kelompok sebesar 7 siswa $(21,87 \%)$ diskusi kelas sebesar 19 siswa $(63,33 \%)$

Pada pertemuan kedua ini guru melakukan apersepsi, guru sudah menjelaskan materi pembelajaran sesuai dnegan rancangan yang telah ditetapkan. Selain itu guru menjawab pertanyaan yang diajukan oleh siswa. Guru terlihat dapat mengelola diskusi dengan baik, sehingga masih banyak siswa yang asyik mendengarkan arahan guru. Guru selalu menganjurkan agar siswa bekerjasama dalam diskusi. Pada pertemuan kedua ini guru merangkum dan menyimpulkan masalah karena waktu yang telah diberikan untuk diskusi.

Guru telah berusaha menciptakan suasana pelajaran yang kondusif. Hal ini terlihat adanya peningkatan adanya peran guru pada setiap pertemuan, bahkan pada pertemuan 5 dan 6 peran guru dalam kelas dapat dikatakan sempurna. Hanya saja pada pertemuan 1 sampai 3 ada hasil belajar guru yang belum muncul (belum dilakukan) yaitu mengajukan pertanyaan siswa. Hal inin terjadi karena guru baru pertama kali sehingga masih ada yang lupa. Selain itu hasil belajar guru memberi kesimpulan tidak mencukupi.

Data diketahui bahwa setiap hasil belajar guru pada siklus akhir mengalami peningkatan, walaupun ada yang pada siklus I dan silkus II pertemuan I guru tidak melakukan yitu mengajukan pertenyaan siswa. Selain itu pada siklus I guru tidak melakukan kesimpulan karena waktu habis evaluasi kerja kelompok dengan tanya jawab.

Tabel 10. Hasil Belajar Guru Pada Pertemuan I, Siklus II

\begin{tabular}{|c|c|c|}
\hline Aspek yang diamati & Ya & Tidak \\
\hline 1.Melakukan apersepsi & $\checkmark$ & \\
\hline 2. Menjelaskan materi & $\checkmark$ & \\
\hline 3. Mengajukan pertanyaan & $\checkmark$ & \\
\hline $\begin{array}{l}\text { 4. Menjawab pertanyaan } \\
\text { siswa }\end{array}$ & $\checkmark$ & \\
\hline 5. Memberi komentar siswa & $\checkmark$ & \\
\hline 6. Memunculkan masalah & $\checkmark$ & \\
\hline 7. Menyimpulkan diskusi & $\checkmark$ & \\
\hline 8. Membentuk kelompok & $\checkmark$ & \\
\hline $\begin{array}{l}\text { 9. Menentukan waktu } \\
\text { lamanya diskusi }\end{array}$ & $\checkmark$ & \\
\hline 10. Mengarahkan & $\checkmark$ & \\
\hline 11. Memantau kerja sisv & $\checkmark$ & \\
\hline
\end{tabular}

Siswa mempelajari sendiri materi pelajaran dengan model picture and picture dalam kelompok masing-masing. Tujuannya agar siswa lebih aktif dan kreatif dalam belajar sendiri tanpa diberikan 
terlebih dahulu oleh guru, disini guru hanya mengarahkan dan membimbing saja.

Sedangkan pada siklus II metode yang digunakan adalah pemecahan masalah dan dipadukan dengan ceramah dan tanya jawab, sehingga hasilnya mengalami peningkatan dibandingkan dengan siklus-siklus sebelumnya.

Hasil penelitian dan pembahasan di atas dapat disimpulkan bahwa penerapan model picture and picture untuk meningkatkan hasil belajar siswa dalam pembelajaran PKn pada siswa kelas X AP 3 telah berhasil. Hal ini dapat dibuktikan dengan perolehan nilai rata-rata pada setiap siklus yaitu siklus I sebesar 67,25 siklus II 83,43.

\section{KESIMPULAN DAN SARAN}

\section{A. Kesimpulan}

Berdasarkan data dan analisis data sebagimana yang telah diuraikan beberapa kesimpulan serta saran-saran. Adapun kesimpulanya adalah sebagai berikut :

1. Pembelajaran pada siklus I ini dilakukan agar siswa dapat memahami materi ras,agama dan budaya dengan penerapan model picture and picture. Pada siklus I ini belum dilaksanakan secara optimal, karena siswa belum terbiasa dengan metode ini, sehingga hasil belajar yang diharapkan belum maksimal. Hasil belajar siswa dalam mengikuti pembelajaran masih bingung dengan metode pembalajaran yang dilaksanakan oleh guru. Selain itu diperoleh nilai rata-rata 6,93 karena siswa belum terbiasa menggunakan model picture and picture yang masih baru dan asing bagi mareka

2. Berdasarkan hasil refleksi yang telah dilakukan maka diperoleh hasil pada siklus II yang ratarata tes hasil belajar siswa diperoleh 83,43 dimana 29 orang siswa $(90,62$ ) siswa sudah mencapai tingkat ketuntasan belajar, sedangkan 3 orang siswa $(9,37)$ belum mencapai tingkatan ketuntasan belajar. Dilihat dari pengamatan selama proses pembelajaran berlangsung siswa sudah memahami materi dan tujuan pembelajaran berlangsung siswa sudah memahami materi dan tujuan pembelajaran yang akan diajarkan. Keatifan dan keberanian siswa dalam mengikuti setiap kegiatan yang dilakukan sehingga peningkatan nilai tes dapat tercapai dengan baik.

\section{B. Saran}

Sejalan dengan rumusan masalah serta manfaat penelitian bagi peningkatan mutu penelitian, berikut dikekukakan saran-saran dalam rangka meningkatkan kompetensi guru di dalam meningkatkan kualitas pendidikan.

\section{Kepada Guru.}

a. Guru sebaliknya menggunakan metode yang bervariasi, inovasi dan antraktif dan menyenangkan serta menentang sehingga membangkitkan motivasi belajar siswa, sehingga siswa lebih bersemangat di dalam belajarnya.

b. Pembelajaran denga menggunakan model picture and picture terbukti mampu meningkatkan hasil belajar dan kreativitas belajar siswa. Oleh karena itu guru disarankan menerapkan metode ini dengan baik pada mata pelajaran pendidikan kewarganegaraan di kelas X AP 3 SMK SWAKRYA BINJAI.

\section{Bagi Penelitian}

Perlu penelitian lebih lanjut mengenai penerapan metode pembelajaran yang sesuai dengan mata pelajaran PKn maupun materi pelajaran dimana metode tersebut bisa mengahasilkan prestasi yang maksimal.

\section{DAFTAR PUSTAKA}

Badudu. J.S. Kamus Umum Bahasa Indonesia. ( Pustaka Sinar Harapan, Jakarta : 1996)

Depdikbud, Kedudukan Evaluasi dalam Pembelajaran (Depdikbud, Jakarta, 2002)

Indrakusuma, Amir Daim, Pengantar Interaksi Belajar dan Mengajar. ( Torsito, Bandung, 2003)

Jurnal Rahmat Fauzi Tentang Penerapan Metode Pembelajaran Picture and picture

Koentjaraningrat, Kebudayaan Mentalis dan Pembangunan, ( PT Gremedia Pustaka Utama, Jakarta. 2004)

Komalasari, Kokom, Yusnawan Lubis. Pendidikan Kewarganegaraan. ( Armico, Bandung, 2006)

Kurniasih, Imas \& Berlin Sani. Model Pembelajaran Untuk Meningkatkan 
Profesional Guru. (Penerbit Kata Pena, Jakarta, 2014 )

Muhson, Ali. Jurnal Pendidikan Akutansi Indonesia, ( Vol. VIII. No. 2 - Tahun 2010)

Nasution, S. Didaktik Azas-Azas Mengajar, ( Jermmar Bandung : 2002 )

Sadirman, Arif. S, dkk. Media Pendidikan: Pengertian, Pengembangan dan Manfaatannya. ( Raja Gafindo, Jakarta : 2006 )

Sadirman. Interaksi dan motivasi belajar mengajar .( Rajawali Pres, Jakarta. 2007).
Sudjana, Nana. Penelitian Hasil Proses Belajar Mnegajar. ( PT. Remaja Rosdakarya, Bandung : 2010)

Sugiyono. Metode Penelitian Pendidikan. (Alfabeta, Bandung 2013)

Suryono, Joko. Jurnal Widyatama. (No. 1/ Volume 19/2010).

Wahidmurni, dkk. Evaluasi Pembelajaran, Kompetensi dan Praktek ( NUHA Letera Yogyakarta. 2010)

Wardani, dkk. Penelitian Tindakan Kelas, Jakarta: Universita Terbuka. 2006 )

Wiriatmaja, Rochianti. Metode Penelitian Tindakan Kelas ( Bandung, PPS, UPI dan Remaja Rosdakrya 2005) 